\title{
RECENT DEVELOPMENT OF CORPORATION LAW BY THE SUPREME COURT OF THE UNITED STATES.
}

By George, Wharton Pepper, Esq.

At the end of the century which has seen the birth of the. modern business corporation it may be said without exaggeration that many fundamental questions in regard to the legal status of corporations are still unsettled and that authorities are not at one in regard to the scientific explanation of corporate phenomena of every day occurrence. The nature of a corporation is still under discussion, and it may be doubted whether any six learned judges would to-day give explanations even substantially similar of the difference between corporations and joint stock companies or statutory partnerships. The result of this conflict of opinion in regard to the nature of a corporation is seen in the diversity of doctrine in the matter of the status of persons who have engaged. in business nominally as a corporation but without complying with all the formalities prescribed by the general corporation law under which they are associated. Can a creditor who has dealt with them as a corporation take advantage of the defect in organization and treat the associates as partners? The answer of many authorities is in the negative $\mathrm{e}^{\mathrm{l}}$ and of many others in the affirmative. $^{2}$ Of the former class Morawexz is one who presses the view of a de facto corporation so far $^{3}$ that, to be consistent, he would be compelled to admit that, for some purposes, persons may become in law a corporation without

${ }^{1}$ Cochran v. Amold, 58 Pa. 399 ; Eaton v. Aspinwall, Ig N, Y. IIg; Stout v. Zulick, 48 N. J. Law, 599 ; Morawetz, \& 748-and cases there cited.

${ }^{2}$ Kaiserv. Bank, 56 Iowa, I04; MTorawetz, 8748 -and cases there cited.

${ }^{3} \hat{8} 745$. 
entering into any relation to the state and without deriving from the state the vital spark of corporate life which English jurists ${ }^{4}$ have been wont to hold that the sovereign alone can dispense. In fact he speaks of "the formation of a corporation without .autiority of law." "5 the latter class is PARsons, ${ }^{\mathfrak{b}}$ who would distinguish between defective organization, under a special charter and under a general corporation law, holding that where the state permits self-incorporation, the conditions of immunity must be exactly complied with, or the associates will continue to be partners with an unlimited liability. ${ }^{\top}$ The obvious justice attained as a result of the former view and, the obvious iniustice which would follow from the latter, predispose the mind in favor of limiting the creditor's right to recover. At the same time such an explanation as that of MORAwETz seems so unsound upon principle that one hesitates to accept it. The same remark applies to the theory advocated in New Jersey and elsewhere that the creditor's right will be limited, because the creditor is estopped from questioning the legality of the corporate existence. ${ }^{8}$ It is, perhaps, not too much to expect that the courts will hereafter find the solution of the difficulty in a scrutiny of the true significance of the contract between the creditor and his debtors in such a case, admitting, at the same time, that no corporation of any kind has come into existence. As it would be entirely competent for the creditor of a partnership to agree in express terms that he would limit his right of recourse to the contributions of the partners, ${ }^{9}$ it should seem that no more rational explanation of the true meaning of the contract could be offered in the case suggested than that the parties had done by implication that which they might have accomplished by express words.

'See Pollock and Maitland's History of English Law, p. 470. The chapter on "Fictitious Persons" is extremely interesting and suggestive. (Little, Brown \& Co., Boston. I895.)

${ }^{5}$ See Vol. II, Chap. IX.

${ }^{6}$ Parsons, (James) : Partnership, 324.

i Parsons answers satisfactorily the argument of Morawetz, that if members of a de facto corporation are not protected from partnership liability, the stockholders of a corporation de jure must be charged individually for ultra vires acts, \& 24 .

${ }^{8}$ Stout v. Zulick, 48 N. J. Law, 599.

${ }^{9}$ Brown v. Slate Co., I34 Mass. 590. 
- There is great diversity of opinion in regard to many of the most.important questions relating to corporate mortgages. To what extent is it true that corporate bonds are negotiable? What is the legal effect of the certificate by a mortgage trustee endorsed upon a bond that the bond is what it purports to be, and that it is entitled to the security of a certain mortgage or trust deed? How far can a subsequent holder of a bond compel the performance by the corporation mortgagor of covenants in the mortgage instrument that the mortgagor will use the borrowed moneys to feed the lender's security? What is the standard of the duties of a mortgage trustee? These are questions of vital importance. If there is any doubt that the law on these subjects is unsettled, a reference to Belden v. Burke ${ }^{10}$ will dispel the doubt. The views of the court below and of the Supreme Court of New York disclose a great diversity of view; and while the conclusion of the Supreme Court seems to be undoubtedly correct many of the questions involved may be said to be of "first impression."

Again, there are almost as many views of corporate pozer in England and in this country as there are tribunals with jurisdiction to pass upon the question. What contracts may a corporation make? On what theory may it make them? What are the rights of parties to an unauthorized or prohibited contract after it has been wholly or partially performed? What is the true distinction between the strictly private corporation and the so-called "quasi-public" corporation in this respect?

Again, in what sense, if in any sense, is the property of a corporation a trust fund for the payment of creditors? Is a stockholder, who has not yet paid the instalments on his shares. entitled to set off against the corporation's claim, a debt due by the corporation to him? If not, (and it has been decided by high authority that he is not so entitled,) ${ }^{11}$ what is the true ground upon which to base the denial of his right? Can a corporation prefer its creditors? Is MoRAwETz right

${ }^{10} 79$ Hun. 5 I.

"Sawyer v. Hoag, I7 Wall. 6 Io. 
in contending that a preference is in conflict with principle? ${ }^{12}$ Or, is it true that until an insolvent corporation gets into the hands of a court of equity, it has the same power of disposition over its assets as if it were a natural person $?^{13}$ If a preference in favor of a general creditor is permitted, is the rule the same where that creditor is also a stockholder? If the preference is permitted in favor of a stockholder, what is to be said of a case in which the preferred creditor is a director? ${ }^{14}$ Can an unsecured creditor file a bill in equity against the stockholders of a corporation without first obtaining a judgment at law, calling upon them to pay the instalments which remain unpaid upon their stock? If not, (and the Supreme Court of the United States has decided that a creditor has no such right,) ${ }^{15}$ how can the court consistently continue to assert that the capital stock of a corporation paid and unpaid is affected with a trust in favor of creditors ? ${ }^{16}$

No decisions are more interesting than those decisions of the Supreme Court of the United States, in which during the iast five years that august tribunal has discussed the questions which fall under the last two heads just referred to- "Corporate Power" and the "Rights of Stockholders and Creditors in the Property of the Corporation." It is proposed to take a brief survey of the most important recent decisions of the court which deal with these problems.

\section{Corporate Power.}

The five-year period, which has been arbitrarily selected for examination, may be said to be marked in its beginning by the decision in Central Transportation Company v. Pullman's Palace Car Company, ${ }^{17}$ which was argued in January, 1890. The decision in that case is well known to the profession. A corporation was organized under the general manufacturing

${ }^{12} \% \mathrm{So3}$.

${ }^{13}$ Graham v. R. R., I02 U. S. 148 ; Hollins v. Briersfield, etc., Co., ' I5O U. S. 371 .

"Re Wincham Co., L. R. 9 Ch. Div. 522 ; Opinion of JESSEL, M. R.

${ }^{15}$ Hollins v. Brierfield Co., 150 U. S. 37I.

${ }^{16}$ Case v. Beauregard, 99 U. S. IIg.

${ }^{1 i}$ I39 U. S. 24. 
corporation law of Pennsylvania, and the purpose of its incorporation was stated to be "the transportation of passengers in railroad cars constructed and to be owned by the said company" under certain patents. The Pullman's Palace Car Company was desirous of obtaining a lease of all the cars of the Pennsylvania corporation, and, in order that all doubt as to the right of the latter to make such a contract might be removed, application was made to the Legislature for a special act, which extended the period of corporate existence for a term of years, authorized an increase of its capital stock and expressly empowered it "to enter into contracts with corporations of this or any other state for the leasing or hiring and transfer to them, or any of them," of its "railway cars and other personal property." Eight days after the passage of this act the lease was executed, and for some sixteen or seventeen years the company lessee paid the stipulated rental when and as the same became due. The company lessee, at the end of a nine months' period for which no rental had been paid, refused to pay upon the lessor's demand on the ground that the contract of lease was unauthorized and, therefore, unlawful and void. In this position the lessee was sustained by the Supreme Court of the United States, Mr. Justice GRAY delivering the opinion. He adopted the view that the corporation lessor, originally a strictly private corporation organized like large numbers of others in Pennsylvania under the general manufacturing corporation law, became a quasi-public corporation with public duties to perform in virtue of the special act, which increased the duration of its corporate life and authorized an increase of its capital stock. The corporation being, in this view, a corporation with public duties to perform, it could make no lease of its property without legislative consent; and he voiced the opinion of the court to the effect that the legislative authority to make a lease could not, in this case, be construed to authorize a lease of all the property of the corporation, since such a contract would involve the abdication by the corporation of the powers which it possessed, and the cessation by it of the performance of the duties imposed upon it by law. Having decided that the contract of lease was 
"urilawful and void, because it was beyond the powers conferred upon the plaintiff by the Legislature," the court decided that no performance on either side could give the unlawful cortract any validity or be the foundation of any right of action upon it. "Whether this plaintiff could maintain any action against this defendant in the nature of a quantum meruit, or otherwise, independently of the contract need not be considered, because it is not presented by this record, and has not been argued. This action, according to the declaration and the evidence, was brought and prosecuted for the single purpose of recovering sums, which the defendant had agreed to pay by the unlawful contract, and which, for the reasons and upon the authorities above cited, the defendant is not liable for." Mr. Justice GRAY thus states the reason for the rule, which is applied in this case: "A contract of a corporation, which is ultra vires in the proper sense, that is to say, outside the object of its creation as defined in the law of its its organization, and, therefore, beyond the powers conferred upon it by the Legislature, is not voidable only, but wholly void and of no legal effect. The objection to the contract is not merely that the corporation ought not to have made it, but that it could not make it. The contract cannot be ratified by either party, because it could not have been authorized by either."

It is clear from this opinion that the Supreme Court of the United States must have worked out a theory of its own as to the distinction between a strictly private and a quasi-public corporation. It is not to be supposed that the court would have decided that a company organized under a general manufacturing corporation law was a quasi-public corporation with public duties to perform had the special act of Legislature been absent from the consideration. That act of Legislature contained but three provisions. The provision authorizing a lease may be disregarded. It certainly could not be relied upon as indicating a legislative intention to turn a manufacturing company into a quasi-public corporation, because the power to lease is confessedly inconsistent with the nature of a quasi-public corporation and special permission 
must be obtained from the sovereign, in order to give the contract validity. It must be, therefore, that the Supreme Court of the United States holds to the view that an increase in the term of existence of a manufacturing company or a permission to increase its capital stock, or both elements conjointly, will be sufficient to work the change. But suppose that the lengthening of the corporate life and the increase of the capital stock had been authorized by a general law applicable to all manufacturing corporations; is it to be supposed that all the manufacturing companies in the state would then have become quasi-public corporations without power to lease their plants? Such a conclusion would never be reached by any court. Are we to suppose, then, that the transformation in this case was wrought in virtue of the circumstance that the enabling act was a special and not a general law? No reason occurs to the writer why any significance should be attached to the distinction; and yet there is no escaping the conclusion that somewhere within the compass of this short and commonplace act there is contained the provision which creates a new relation between the corporation and the public, which gives to the public an added interest in the performance by the corporation of its functions and imposes upon the corporation new and more serious duties to perform. The practical conclusion is that manufacturing corporations must beware of legislation enacted for their benefit, as it is not yet clear what language will bring about a state of things that is not in the contemplation of the Legislature which enacts the law, nor of the corporation which accepts it.

Assuming the corporation to be a quasi-public corporation, there was abundant authority for the proposition that the lease, to be valid, must receive legislative sanction. Some years before, in Thomas $v$. Railroad Company, ${ }^{\text {s }}$ the law upon this point was definitely settled by the Supreme Court. It is interesting to note, however, that even this conclusion was questioned by no less distinguished a jurist than Mr. Justice Bradley. In Pennsyláania Co. et al. v. St. Louis, Alton \&

${ }^{18}$ IOI U. S. 71. 
Torre Hante $R, R, C o_{,}{ }^{19}$ decided about five years earlier than the case under discussion, he filed a dissenting opinion, in which he made a powerful statement of the reasons why the English notions on the subject of railway leases are inapplicable to our situation and circumstances, "however well suited to that compact and homogeneous country." That was a case, in which the company lessor had full authority to make the lease, and the invalidity of the contract depended upon the lack of power on the part of the lessee to accept it. Mr. Justice BradLey's language is general, however, and applies equally well to cases, in which there has been been no specific grant of authority to make the lease on the part of the lessor. His position substantially was that the interests of the public are, as a rule, better subserved by a system of railway leases by which continuous lines for the transportation of passenger's and freight are secured, than would be the case if transportation across the continent could be obtained only by means of successive independent lines of railway. It will be observed that he confined his remarks to leases. There is nothing in his opinion, which would justify the criticism that he loses sight of the principle that a franchise to run a railroad is a personal privilege in the sense that it cannot be sold or transferred absolutely without legislative consent. Four years before, in Branch v. Jesup," which was a case of outand-out sale, Mr. Justice BradLEy had said: "We do not mean in the slightest degree to disaffirm the general rule that a corporation cannot dispose of its franchises to another corporation without legislative authority. But we think that the authority clearly existed in this case."

It seems, however, in spite of Mr. Justice BradLEy's vigorous expression of opinion that the Supreme Court makes no distinction between a lease and an out-and-out sale. Both require legislative sanction as a condition of validity wherever the leasing or selling company is a quasi-public corporation. Just why the Act of the Pennsylvania Legislature in the case under discussion fell short of what is required in such

39 IIS U. S. 290 ,

${ }^{20}$ I06 U. S. 468 , 
cases is not clear to the writer. Mr. Justice GRAY speaks of the "evident purpose" of the Legislature in passing the statute and says, in effect, that a general power to lease cannot be construed to authorize a general lease, "without much clearer expressions of the legislative will looking towards the end than are to be found in this statute." This, however, is probably a question of original apprehension, and is, therefore, one of those points, which it is not profitable to discuss.

The position definitely taken by the court in the matter of the inability of a plaintiff, who has performed an unauthorized contract, to recover upon it from the defendant, is a position full of practical and speculative interest. In his dissenting opinion, already quoted, Mr. Justice BradLEY, in the earlier case, had said: "The contract has been performed on the part of the lessor company and the lessee, and its guarantors have enjoyed the benefit of it. With what face can they now refuse to pay what they agreed to pay? With what face can they plead incapacity to contract? This is not a suit to compel the specific performance of the contract in future; but to compel the payment of the money earned by past performance of the contract. It seems to me that the companies concerned are estopped to deny their liability to make this payment." He was speaking of a case, in which the corporations which desired the benefit of a lease had formed a straw corporation to accept it, and had guaranteed the payment of the rentals accruing to the lessor. The court held, in that case (after deciding that the straw corporation had no authority to accept the lease,) that the covenants of guaranty were covenants to insure the doing of a thing itself invalid, and were, therefore, unenforcible. When a petition for a re-argument was filed the court refused to hold that the contracts of guaranty were in substance original covenants to pay rent, the guarantors being the promoters of the lease and being, in effect, the original lessees. Although Mr. Justice MILler, in form dealt with the case as an ordinary case in which the original party in interest was the lessee named in the lease, it seems in reality difficult to distinguish the case from Central Transportation Company v. Pullman's Palace Car Company, 
cxcepting with reference to the fact that in the earlier case it was the lessee corporation which was incompetent to make the contract, and in the later case it was the lessor who. lacked the power. It should seem that Mr. Justice BradLEy's protest was as applicable in the latter case as in the former. Mr. Justice Grar, however, spoke with no uncertain voice. In addition to the passage from his opinion which has already been quoted, it is interesting to notice the following extract: "A contract ultra zircs being invalid and void, not because it is in itself immoral, but because the corporation by the law of its creation is incapable of making it, the courts, while refusing to maintain any action upon the unlawful contract, have always striven to do justice between the parties so far as could be done consistently with adherence to law by permitting property or money parted with on the faith of the unlawful contract to be recovered back or compensation to be made for it. In such case, however, the action is not maintained upon the unlawful contract, nor according to its terms; but on an implied contract of the defendant to return, cr, failing to do that, to make compensation for property or money, which it has no right to retain. To maintain such an action is not to affirm, but to disaffirm the unlawful contract." The distinction between recovery under an express contract, which the court, in this case, refused to permit, and a recovery of the amount sucd for under an implied contract, which is pernitted in many cases, and is not disapproved by Mr. Justice Gray,. is a distinction, which is somewhat shadowy and difficult to. grasp. Why it is that the interests of the public are best subserved by treating the contract as made by the parties as unenforciblc and substituting an enforcible contract "implied: by law" to accomplish the same result is not clear to the writer. Mr. Justice Gray's language just cited scems to. contemplate a recovery in quasi-contract in the original suit as if the court were dealing with the case of a defendant. in default under an illegal agrcement. But this cannot be the basis of a recovery in any case like the one before the court, because the rule of law, which invalidatcs a railway lease made without legislative authority, is, in no sense, a rule of 
law which exists for the protection of the plaintiff against the defendant, and the parties to the unauthorized contract are accordingly to be treated as in pari delicto. In such cases, it well settled that the plaintiff cannot recover in quasi-contract. $^{21}$ It should seem, therefore, to be a necessary inference from the language of the court that a recovery will be permitted (in cases where a recovery is permitted) on the ground that there is evidence in the case from which an intention upon the part of the defendant to pay may fairly be inferred. In other words, the relief is granted to effectuate the intention of the parties, and not contrary to the intention of the defendant. If this is the true theory of the relief, it is hard to see (as suggested above) why the agreement of the parties should not be enforced upon the basis of the instrument in which it was expressed, instead of upon the basis of an inference from the conduct of the parties induced by the execution of that instrument. The only answer which disposes of this difficulty involves us in a difficulty equally serious. It may be said that the court in refusing to enforce the agreement as written intends to permit a recovery only in those cases in which property or money has actually passed to the defendant on the faith of the unlawful contract and subsists in the hands of the defendant at the time of suit brought. But, if we have left the realm of quasi-contract, and if the basis of relief is a genuine agreement inferred by law from the conduct of the parties, why limit the recovery to cases in which there has actually been an unjust enrichment of the defendant at the expense of the plaintiff? And why not extend the relief, in accordance with the true intention of the parties; to cover the case in which it was evidently, at the outset, the intention of the plaintiff that he should be paid and the intention of the defendant to pay him, although, as affairs have turned out, the defendant has, in fact, derived no benefit from the contract, but has incurred a loss? If this view had been adopted by the court, in Pennsylvania Co. et al. v. St. Louis, Alton \& Terre Haute R. R. Co., (supra), and, if, in that case, the court had regarded the sub${ }^{21}$ See Keener on Quasi-Contracts, page 267, et seq. 
stance of the transaction instead of the form, a recovery would have been permitted upon the ground that the real defendants (in form the guarantors) had purchased from the plaintiff a business opportunity to make a profit under a railway lease, for which opportunity it was evidently the intention of both parties that the defendants should, at all events, pay. The mere circumstance that the expected profit was not fully realized should not deprive the plaintiff of his right to recover on the agreement implied from the conduct of the parties, nor deprive him of his right to give in evidence the unenforcible lease for the purpose of proving the valuation placed by the parties upon the opportunity afforded by the plaintiff to the defendants. Even, if the court were to refuse to permit a recovery to this extent, surely upon the theory of a contract inferred by law from the conduct of the parties, a recovery should be permitted in such a case as the one under discussion. In Central Transportation Co.v. Pullman's Palace Car $C_{0}$., there was an actual enrichment of the defendant at the expense of the plaintiff. The defendant had used the plaintiff's property and had made a profit out of it. Is it possible that the defendant, on account of the unlawfulness of the contract, can retain the advantage which he has obtained at the expense of the plaintiff? The answer of the court is that, for the purposes of a suit founded upon the unlawful contract, the response to this question must be in the affirmative, unless the advantage is money or tangible property, which has actually passed from the hands of the plaintiff into the hands of the defendant. The court then proceeds to intimate that it is an arguable question whether a recovery could be had in an independent suit "upon the quantum menuit or otherwise." Since it is clear that no recovery can be had upon a quasicontractual obligation, and, that, if a recovery is to be permitted at all, it is upon the basis of a genuine contract, it should seem to be purely arbitrary to permit a recovery in the original suit in some cases and to drive the plaintiff to an independent suit in other cases; and, in general, to refuse in any form of action to enforce the contract which the parties. have made, substituting for it a contract which the parties did 
not make, and enforcing that. In fine, it is difficult to understand, upon principle, how it is, in any cases of this class, that the court can avoid the conclusion that the contract must be enforced as it was made, or else that the parties must, in all cases, be left in the position in which they have placed themselves.

If this dilemma were recognized as sound, it is conceived that it would not be long before the Supreme Court of the United States would adopt what is conceived to be the modern view of unauthorized, and even of prohibited corporate contracts-namely, that they will be enforced as between the parties to them precisely as if they were the contracts of natural persons. The term ultra vires would have, in that event, no significance except in the case of suits in equity by stockholders to restrain the making of contracts, or in quo warranto proceedings instituted by the state in cases where such unauthorized or prohibited contracts have been actually made.

It should seem to be clear from the language of $\mathrm{Mr}$. Justice Gray, in Central Transportation Co. v. Pullman's Palace Car Co., ${ }^{22}$ that it is the legal duty of a corporation, which is a party to an unauthorized or prohibited contract "to rescind and abandon the contract at the earliest moment, and the performance of that duty, though delayed for several years," is " a rightful act when done." If, in the case discussed above, the lessor, before the defendant had made default in the rentals, had notified the defendant of his disaffirmance of the contract, it should seem that he would have been doing no more than his duty, and that he would have been entitled to recover from the lessee in quasi-contract for the benefits conferred upon the defendant under the lease. It will be observed that in such a case the suit would not be instituted to recover compensation from the defendant or to recover the equivalent of what would have been received if the invalid contract were completely executed. The plaintiff would be seeking to be reinstated in his former position by a return of the property,

22 Page 55. 
which is the subject-matter of the contract. ${ }^{23}$ In such a case, the inquiry is not as to whether the parties are in pari delicto, but as to whether the illegality of the contract is in the nature of malum in se or malum prohibitum. ${ }^{24}$ Assuming for the purposes of this discussion that there is a real distinction between malum in se and malim prohibitum, it is clear from Mr. Justice Grar"s ópinion that an unauthorized railway lease is malum prifibitum merely. The right of the lessor to recover, therefore, would seem to be undoubted. The standing of a plaintiff in such a case was emphatically recognized in Congress Spring Co. v. Knowlton, ${ }^{25}$ which carries the doctrine of the plaintiff's right to a recovery under an illegal contract somewhat farther than any other case in the books. It is difficult to understand, therefore, the meaning of the decision of the Supreme Court in St. Louis, Vandalia \& Terre Haute, $\dot{R} . R$. Co. v. Terre Haute and Indianapolis $R . R$. Co $^{20}$ In that case a railway lease had been made by plaintiff to defendant, and for a term of sixteen or seventeen years the defendant had been in possession under the lease and had paid rental in accordance with its terms. At the expiration of that period, but long before the end of the term, the plaintiff lessor filed a bill in equity to set aside and cancel the lease on the ground of illegality and prayed for a return of the property. The Supreme Court held under the decision in Peninsylziania Railroad v. St. Louis, Alton \& Terre Haute, R. R. (supra), that "the contract in question was ultra zires of the defendant, and therefore did not bind either party and neither party could have maintained a suit upon it at law or in equity against the other." Mr. Justice GRAY delivered the opinion of the court, and after using the language just cited, he remarked : "It does not, however, follow that this suit to set aside and cancel the contract can be maintained." He proceeds tơ announce that "the general rule; in equity; as at law, is iti pari delicto potior est conditio defendentis; and therefore neitfier

\footnotetext{
${ }^{23}$ S̈̉èe Ke'ner on Quasi-Contracts, pàğe $26 \dot{6}$.

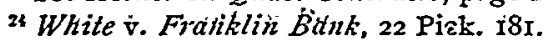

${ }^{25}$ ib3 $\tau$ : S. S9. 49 .

${ }^{26} 145$ C.S. S. [189I].
} 
pariy to an illegal contract will be aided by the court, whether to enforce it or to set it aside. If the contract is illegal, affirmative relief against it will not be granted at law or in equity uniess the contract remains executory, or unless the parties are considered not in equal fault, as where the law violated is intended for the coercion of the one party, and the protection of the other, or where there has been fraud or oppression on the part of the defendant: Thomas v. Richmond, I 2 Wail. 349, 355 ; Spring Co. v. Knowlton, I03 U. S. 49 ; Story Eq. Jur. Sec. 298." Again he says: "When the parties are in pari delicto, and the contract has been fully executed on the part of the plaintiff, by the conveyance of property, or by the payment of money, and has not been repudiated by the defendant, it is now equally well settled that neither a court of law nor a court of equity will assist the plaintiff to recover back the property conveyed or money paid under the contract: Thomas v. Richmond, above cited; Ayerst v. Jenkins, L. R. 16 Eq. 275, 284." The opinion of the court was that since the lease was invalid and the parties in pari delicto, and since the contract had been fully executed on the part of the plaintiff, by the transfer of its property to the defendant, who had held the property and paid the stipulated consideration for seventeen years, the court would not grant the relief prayed for by the plaintiff and would take no steps to compel the return of the property by the defendant.

Surely there is abundant food for reflection in this decision. The conclusion is precisely the reverse of what the language of the court in Central Transportation Company v. Pulman's Palace Car Co., would lead a lawyer to expect. If there really is a duty upon the part of a party to an invalid contract, wholly or in part executory, to take active steps to rescind it at the earliest possible moment, it is difficult to see why the court should not be active in effectuating a performance of the duty. That there is a duty upon the part of a corporation which has become party to an unauthorized delegation of corporate franchises to endeavor to re-establish the status quo in favor of an injured public, is a conclusion that seems to follow logically from the premises recognized by the court. Is it 
possible that the Supreme Court of the United States means to deny the proposition that a party to an illegal contract, not wholly executed, may give notice of disaffirmance to a defendant who is not in default and recover from the defendant such property as will result in putting both parties in the position in which they were before the illegal contract was made? It should seem that the right is clearly recognized, as already stated, in Spring Co. v. Knowolton, (supra), and it is not denied in any of the cases cited by Mr. Justice GRAY in support of his conclusion. In some of those cases, indeed (as in Thomas v. Richmond), a recovery was refused, but that was the case in which the defendant was in default under an illegal contract, and the plaintiff was declared to be in pari delicto; but where the defendant is not in default and the illegality of the contract is malum prohibitum merely, a mass of authority supports the proposition that the plaintiff is entitled to the aid of the court to make his disaffirmance of the contract effectual. ${ }^{27}$ In the case under discussion an obligation existed, by the terms of the contract on the part of the defendant, in favor of the plaintiff, to continue the payment of rental for a long term of years. The court intimates that if the defendant were to refuse to pay, and (as in the case of Central Transportation Co. v. Pullman's Palace Car Co.), were to make default under the contract, the plaintiff would have no standing to sue upon the lease for the unpaid rental. In other words, the position taken in the lastmentioned case is reaffirmed. But if this is so, one of two results must follow: either, in the event of a default on the part of the defendant, the court will refuse to permit a recovery by the plaintiff on a quantum menit; or the court in such a case would permit the recovery. If the former alternative is -adopted, a question left unsolved in the earlier decision must be taken to be settled against the right of the lessor. If the latter alternative is adopted, then the decision under discussion is in substance a decision which permits the continuance of an illegal arrangement, under which the plaintiff may have the aid of a court to enforce a claim against the defendant in case the defendant should ever make default. In other words, the

${ }^{2 i}$ See Keener on Quasi-Contract, p. 258, et seq. 
court announces that the making of an unauthorized leaseis invalid and that it is a menace to the welfare of the public.. When the plaintiff desires to terminate it, the court refuses to lend its aid to effectuate the rescission. When, ultimately, the defendant makes default and refuses to pay rental for the period of occupation the court permits a recovery, not, indeed, upon ths express contract, but upon a contract implied. Either conclusion is unsatisfactory, and it may be suggested with deference that the decision is ingeniously contrived to work to the disadvantage of the public and the plaintiff if one alternative is adopted, and to the disadvantage of the public and the defendant if the court accepts the other.

If the result of these decisions were to be summed up in a series of propositions, it is conceived that those propositions would be somewhat as follows:

Where an unauthorized corporate contract has been made, neither party can maintain an action upon it against the other.

If one of the parties does institute an action upon the contract against the other, the court, while declaring his action unfounded, will award to him a recovery in that suit of money or property obtained from him by the defendant upon the faith of the contract.

If the claim of the plaintiff cannot be treated specifically as a claim for property or money obtained by the defendant on the faith of the contract, he can recover nothing in the original suit upon the express contract.

If the defendant has received any other benefit under the contract, it is doubtful whether or not the plaintiff will succeed in a suit against-the defendant founded upon a quantum meruit.

If the suit upon the quantum meruit cannot be maintained, the iessee under an unauthorized railway lease has the lessor at his mercy to the extent that he may elect to terminate the lease at any time, and, upon returning the subject-matter, may. refuse with impunity to make compensation to the plaintiff for benefits received from the use of it.

If the suit upon the quantum meruit can be maintained, the 